\title{
Analisis Faktor Konfirmatori Terhadap Alat Ukur Kesehatan Mental Berdasarkan Teori Dual Model
}

\author{
Rahmat Aziz \\ azira@uin-malang.ac.id
}

\author{
Zamroni \\ zamroni.psi@uin-malang.ac.id
}

Fakultas Psikologi Universitas Islam Negeri Maulana Malik Ibrahim Malang

\begin{abstract}
This study aims to test mental health inventory using a dual model theory approach. The subjects were 520 students (179 men and 341 women) in the age of 17-24 years. Confirmatory factor analysis used for testing the construct validity of mental health inventory. There are two aspects tested in the structural equation model (SEM), namely 1) the psychological well-being aspect consists of three factors namely positive emotions, love and satisfaction, and 2) the psychological distress aspect consists of three factors namely anxiety, depression and loss of control. The results showed that the mental health inventory had met the psychometric requirements. In psychological well-being aspect all aspects have a high level of reliability, whereas for psychological distress aspect one aspect has a high category and two aspects have a sufficient category.
\end{abstract}

Keywords: confirmatory factor analysis, mental health, dual model theory

\begin{abstract}
Abstrak
Penelitian ini bertujuan untuk menguji alat ukur kesehatan mental dengan menggunakan pendekatan teori dual model. Subjek penelitian sebanyak 520 mahasiswa (179 laki-laki dan 341 perempuan) dalam usia 17-24 tahun. Analisis faktor konfirmatori menjadi dasar untuk pengujian validitas konstruk alat ukur kesehatan mental. Ada dua aspek yang diuji dalam model persamaan structural (SEM), yaitu 1) aspek psychological well-being terdiri dari tiga faktor yaitu emosi positif, cinta dan kepuasan, dan 2) aspek psychological distress terdiri dari tiga faktor yaitu cemas, depresi dan kehilangan kontrol. Hasil penelitian menunjukkan bahwa alat ukur kesehatan mental telah memenuhi persyaratan psikometrik. Pada aspek psychological well-being semua aspek mempunyai tingkat reliabiltas yang tinggi, sedangkan untuk aspek psychological distress satu aspek mempunyai kategori tinggi dan dua aspek mempunyai kategori cukup.
\end{abstract}

Kata kunci: analisis faktor konfirmatori, kesehatan mental, teori dual model

Psikoislamika: Jurnal Psikologi dan Psikologi Islam (JPPI) Volume 16. Nomor 2. Tahun 2019. Copyright @ 2019 . Pusat Penelitian dan Layanan Psikologi.

\section{PENDAHULUAN}

Kajian tentang kesehatan mental memang merupakan suatu kajian yang menarik dan penting untuk diteliti karena pada dasarnya setiap orang selalu mendambakan kesehatan dalam hidupnya. Dalam pandangan psikologi, kesehatan mental dapat didefinisikan menjadi dua pola yaitu pola negatif yang mendefinisikan kesehatan mental sebagai suatu kondisi terhindarnya seseorang dari segala gangguan neurosis dan psikosis. Pola kedua adalah pola positif yang mendefinisikan kesehatan mental sebagai kemampuan individu dalam penyesuaian diri sendiri dan terhadap lingkungan sosialnya.

Pada awal kajian tentang kesehatan mental, penjelasan mengenai kesehatan mental sering didefinisikan sebagai pola negatif berupa terhindarnya dari penyakitpenyakit mental seperti cemas, depresi, kehilangan kontrol dan lain sebagainya. Saat ini, seiring dengan perkembangan aliran psikologi positif, perhatian terhadap pola positif semakin diperhatikan sehingga kesehatan mental dapat diartikan dengan pendekatan pertama dan kedua secara bersamaan. Pendekatan ini didasari 
anggapan bahwa kondisi positif dan negatif bukanlah suatu yang pasti bertentangan, tetapi merupakan kondisi yang mungkin ada pada individu disaat yang bersamaan.

Kajian tentang kesehatan mental pada aspek positif atau kesejahteraan psikologis (well-being) telah dilakukan juga. Salah satu studi yang paling kuat adalah yang berfokus pada hubungan antara kesejahteraan dan kesehatan fisik dan perannya dalam masalah sosial-ekonomi dan pembangunan ekonomi (Bartels, 2015). Studi lain telah menemukan bahwa kesejahteraan yang tinggi dapat memprediksi umur panjang di antara populasi orang sehat (Steptoe, O'Donnell, Marmot, \& Wardle, 2008). Studi kesejahteraan sangat penting karena tingkat kesejahteraan yang tinggi dikaitkan dengan manfaat luar biasa termasuk peningkatan kesehatan, kebahagiaan, kebermaknaan hidup, peningkatan umur panjang, kesuksesan karier, peningkatan kualitas hubungan sosial, dan peningkatan fungsi kognitif (Kirkcaldy, 2015).

Beberapa penelitian yang mengkaji kesehatan mental dari aspek negatif telah banyak dilakukan juga. Misalnya penelitian menunjukkan bahwa stres pada siswa terkait erat dengan tuntutan tinggi pada tugas akademik (Meixner et al., 2019), pengalaman emosional dan sosial dalam berinteraksi dengan orang lain (Heinen, Bullinger, \& Kocalevent, 2017), penggunaan minuman keras dan obat-obat terlarang (Tavolacci et al., 2013). Data lain menunjukkan bahwa stres memiliki efek mendalam pada kesehatan fisik dan emosional siswa (Nugraha, Ernawati, Harijanti, \& Parmadiati, 2018). Temuan lainnya menunjukkan bahwa stres sebagian berkontribusi pada munculnya gejala depresi dan tingkat kecemasan yang tinggi (Wahyuni, Anies, Soejoenoes, \& Putra, 2019).

Penelitian ini bertujuan untuk menguji alat ukur kesehatan mental dengan menggunakan analisis faktor konfirmatori. Pengujian pertama bertujuan untuk mengetahui tingkat reliabilitas dan validitas konstruk kesehatan mental. Tujuan kedua bertujuan untuk menguji reliabilitas dan validitas konstruk kesehatan mental aspek psychological well-being, dan tujuan ketiga untuk menguji reliabilitas dan validitas konstruk kesehatan mental aspek psychological distress.

Organisasi Kesehatan Dunia (World Health Organization) mendefinisikan kesehatan mental "a state of well-being in which the individual realizes his or her own abilities, can cope with the normal stresses of life, can work productively and fruitfully, and is able to make a contribution to his or her community ". Pada definisi tersebut dapat dipahami bahwa kesehatan mental diartikan sebagai kondisi sejahtera yang dirasakan individu, di mana dia menyadari kemampuannya, dapat mengatasi tekanantekanan dalam kehidupannya, dapat bekerja secara baik dan produktif, serta mampu memberi kontribusi kepada masyarakatnya (Organization \& others, 2004).

Definisi lain tentang kesehatan mental dikemukakan juga oleh Taylor \& Brown (1988) yang menyatakan bahwa, manusia yang memiliki kesehatan mental adalah manusia yang memiliki kemampuan menerima dirinya dan lingkungannya tanpa merasa kecewa dan mengeluh. Mereka dapat menerima sifat-sifat yang ada pada dirinya yang mungkin berbeda dengan gambaran ideal dirinya tanpa merasa terbebani.

Pendapat lain dikemukakan oleh Keyes (2002) menyatakan bahwa kesehatan mental memberi kontribusi penting bagi status kesehatan seseorang secara menyeluruh. Kesehatan mental bukan hanya tidak adanya penyakit mental tetapi lebih pada keadaan mental yang sejahtera. Sejalan dengan pendapat di atas dikemukakan oleh Veit \& Ware (1983) yang menyatakan bahwa keadaan mental yang sejahtera 
sebagai indikator kesehatan mental itu mencakup dua aspek, yaitu pertama aspek terbebasnya individu dari tekanan psikologis (psychological distress) yang dicirikan dengan tingginya tingkat kecemasan, depresi dan kehilangan kontrol; kedua, terdapatnya kesejahteraan psikologi (psychological wellbeing) yang dicirikan dengan adanya perasaan positif secara umum, kondisi emosional dan kepuasan hidup.

Berdasarkan beberapa definisi tentang kesehatan mental yang telah dikemukakan tersebut dapat disimpulkan bahwa kesehatan mental merupakan keadaan di mana individu merasa sejahtera. Kesehatan mental yang baik ditunjukkan dengan 1) Kemampuan individu untuk mengetahui potensi dirinya dan mampu memaksimalkan potensinya; 2) Kemampuan individu mengatasi kondisikondisi yang menekan dalam hidupnya; 3) Kemampuan individu untuk bekerja secara produktif dan bermanfaat di tempat kerja, keluarga, komunitas, dan di antara teman. Karena itu, kesehatan mental dalam konteks mahasiswa di perguruan tinggi, dapat dijelaskan bahwa individu yang sehat mentalnya adalah individu yang mampu mewujudkan keserasian antara fungsi-fungsi kejiwaan, mampu menyesuaikan dengan dirinya sendiri dan lingkungannya, sehingga menjadi individu yang produktif dan mampu memberi kontribusi positif di lingkungan akademiknya.

\section{METODE}

Subjek penelitian terdiri dari 520 mahasiswa (179 laki-laki dan 341 perempuan) di Universitas Isam Negeri Maulana Malik Ibrahim Malang. Proses pengambilan sampel dilakukan secara proporsional dengan mempertimbangkan keterwakilan tiap fakultas. Usia peserta berkisar antara 17 tahun hingga 24 tahun (rerata usia subjek 19.77 tahun).

Data diperoleh melalui alat ukur kesehatan mental yang merupakan modifikasi terhadap alat ukur The Mental Health Inventory (MHI-38) yang telah dibuat oleh Veit \& Ware (1983). Alat ukur ini telah diuji reliabilitasnya pada dosen dan karyawan di perguruan tinggi dengan menggunakan Rasch Model (Aziz, 2015). Aspek yang diungkap oleh alat ukur ini adalah kondisi kesehatan mental positif (emosi positif, cinta, kepuasan hidup) dan kondisi kesehatan mental negatif (kecemasan, depresi, kehilangan kontrol). Masing-masing indikator terdiri dari empat item sehingga jumlahnya menjadi 24 item. Petunjuk pengisian pada alat ukur ini dimulai dengan perintah: "Gambarkanlah kondisi diri anda sejak sebulan terakhir sampai saat ini. Untuk menjawab pertanyaan seberapa sering mengalami kondisi yang dirasakan". Pada penelitian ini, alat ukur tersebut diuji kembali untuk lebih menyederhanakan jumlah item dan untuk mendapatkan validitas konstruk dari alat ukur tersebut.

Teknik analisis yang digunakan di dalam penelitian ini adalah analisis faktor konfirmatori dengan menggunakan teknik Structural Equation Modeling (SEM). Piranti lunak yang digunakan untuk analisis data adalah AMOS 4.01.

\section{HASIL}

Hasil pengujian reliabilitas pada alat ukur kesehatan mental menghasilkan 12 item terbaik dari yang sebelumnya berjumlah 24 item. Tiap-tiap indikator terdiri dari 2 item. Hasil selengkapnya terdapat pada tabel $1 \mathrm{di}$ bawah ini: 
Tabel 1. Item Pertanyaan Alat Ukur Kesehatan Mental

Psychological Well-being

1. Kehidupan sehari-hari Anda penuh dengan hal-hal yang menarik?

2. Pada umumnya Anda menikmati hal yang dilakukan?

3. Merasa nyaman berkomunikasi dengan teman Anda?

4. Merasa berharga karena perlakuan teman Anda?

5. Merasa bahagia dalam menjalani kehidupan ini?

6. Menikmati apa yang terjadi dalam kehidupan ini?

Psychological Distress

1. Mendapatkan diri Anda sebagai orang yang bingung atau frustasi?

2. Merasakan sebagai orang yang lelah atau merasa tak berdaya?

3. Merasa berada pada titik yang terendah?

4. Menggunakan waktu untuk menikmati rasanya putus asa?

5. Merasa kehilangan kontrol terhadap pikiran, perasaan, dan perilaku?

6. Merasa tidak mempunyai apa-apa dalam menatap masa depan?

Hasil analisis reliabilitas alat ukur kesehatan mental dengan menggunakan teknik konsistensi internal Alpha Cronbach menunjukkan hasil .824. Hal ini berarti bahwa alat ukur tersebut memiliki tingkat reliabilitas yang tinggi. Nilai korelasi item total Psychological Distress terentang dari .486-.603 dan Psychological Well-being terentang dari .667-.757. Hasil reliabilitas pada masing-masing aspek dapat di lihat pada tabel 2 di bawah ini:

Tabel 2. Reliabilitas Aspek Alat Ukur Kesehatan Mental

\begin{tabular}{|c|c|c|c|}
\hline Variabel & Jumlah Item & Reliabilitas & Keterangan \\
\hline 1. Psychological Well-being & 6 & 0,886 & Sangat Baik \\
\hline - Emosi Positif & 2 & 0,716 & Baik \\
\hline - Cinta & 2 & 0,842 & Baik \\
\hline - Kepuasan & 2 & 0,772 & Baik \\
\hline 2. Psychological Distress & 6 & 0,785 & Baik \\
\hline - Kecemasan & 2 & 0,683 & Baik \\
\hline - Depresi & 2 & 0,584 & Cukup \\
\hline - Kehilangan Kontrol & 2 & 0,624 & Cukup \\
\hline
\end{tabular}

Hasil analisis pertama tentang alat ukur kesehatan mental menunjukkan hasil sebagai berikut di gambar 1:

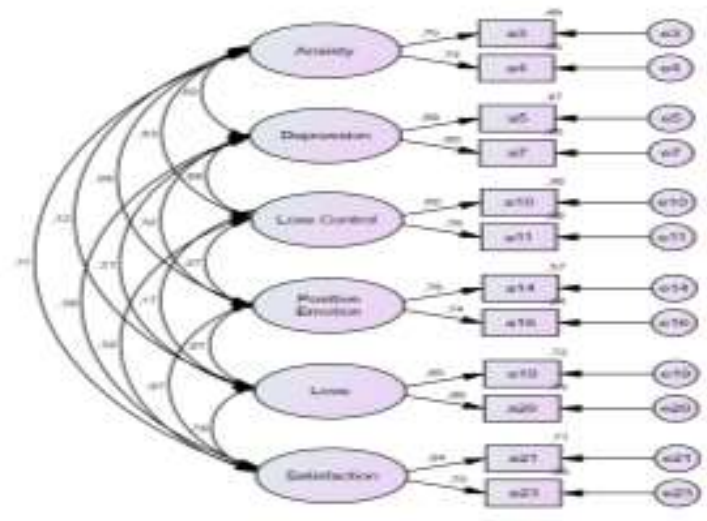

Gambar 1. Dual Model Kesehatan Mental
Indeks goodness of fit menunjukkan bahwa model teoritis dan model empiris telah memenuhi kesamaan yang baik. Hal ini dapat dilihat dari terpenuhinya nilai minimal yang dipersyaratkan pada beberapa indeks. Pada sampel penelitian $(\mathrm{N}=520)$ diperoleh indeks goodness of fit seperti GFI $=.966, \mathrm{AGFI}=.932, \mathrm{TLI}=.947$ (mendekati $.95)$, CFI $=.969$, dan RMSEA $=.061$ sudah memenuhi kelayakan model yang baik.

Hasil analisis kedua tentang alat ukur kesehatan mental pada aspek psychological well-being menunjukkan hasil seperti pada gambar 2: 


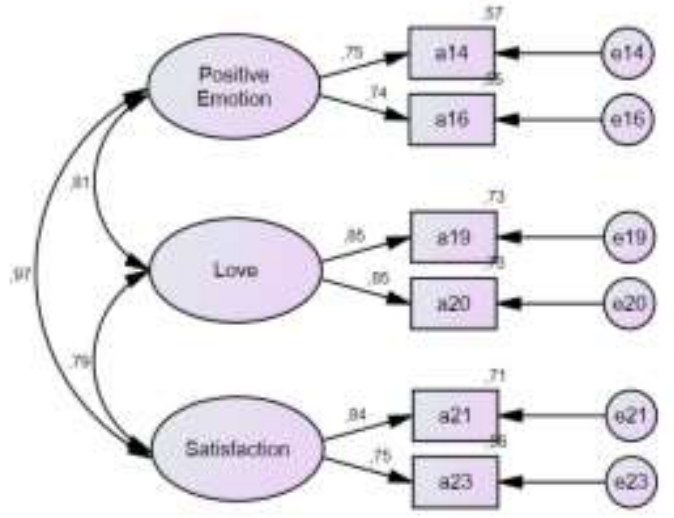

Gambar 2. Model Kesehatan Mental Positif

Indeks goodness of fit menunjukkan bahwa model teoritis dan model empiris telah memenuhi kesamaan yang sangat baik. Hal ini bisa dilihat pada terpenuhinya (bahkan melebihi) nilai minimal yang dipersyaratkan pada masing-masing indeks. Pada sampel penelitian ( $\mathrm{N}=520)$ diperoleh indeks goodness of fit seperti GFI $=994$, AGFI $=981$, TLI $=996$, CFI $=998$, dan RMSEA $=.029$ sudah memenuhi kelayakan model yang baik. Oleh karena itu secara keseluruhan model teoritis dan model empiris tersebut telah menunjukkan kesamaan yang baik.

Hasil analisis ketiga tentang alat ukur kesehatan mental pada aspek psychological distress menunjukkan hasil sebagai berikut di gambar 3:

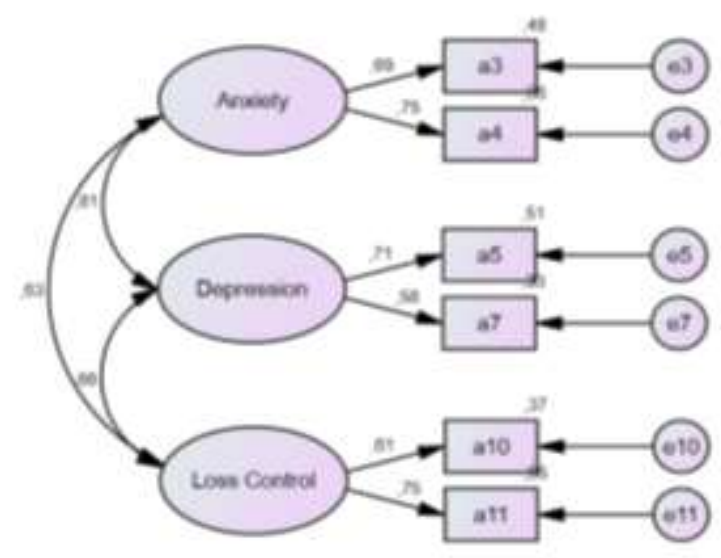

Gambar 3. Model Kesehatan Mental Negatif
Indeks goodness of fit menunjukkan bahwa model teoritis dan model empiris telah memenuhi kesamaan yang sangat baik. Hal ini bisa dilihat pada terpenuhinya (bahkan melebihi) nilai minimal yang dipersyaratkan pada masing-masing indeks. Pada sampel penelitian $(\mathrm{N}=520)$ diperoleh indeks goodness of fit seperti GFI $=994$, AGFI $=978$, TLI $=987$, CFI $=995$, dan RMSEA $=.035$ sudah memenuhi kelayakan model yang baik. Oleh karena itu secara keseluruhan model teoritis dan model empiris tersebut telah menunjukkan kesamaan yang baik.

\section{DISKUSI}

Keberadaan alat ukur kesehatan mental yang memadai (reliabel dan valid) kian terasa peran pentingnya, terutama penggunaannya di kalangan mahasiswa. Minimnya ketersediaan alat ukur dalam mendeteksi kesehatan mental tidak hanya terjadi pada situasi akademik, misalnya mahasiswa, tetapi juga pada situasi kerja sebagaimana dikemukakan Aziz (2015). Padahal kalau ditelusuri lebih jauh tingginya prevalensi stres akademik mahasiswa terjadi secara menyeluruh dari berbagai jurusan sebagaimana penelitian yang dilaporkan oleh Zamroni (2015) di Universitas Islam Negeri Maulana Malik Ibrahim Malang. Kondisi ini menunjukkan bahwa alat ukur kesehatan mental sangat dibutuhkan sebagai langkah awal pemetaan kondisi mental psikologis mahasiswa.

Alat ukur kesehatan mental yang berjumlah 12 item pertanyaan ini menunjukkan reliabilitas (.824) yang baik sebagai properti tes psikologi. Instrumen yang dikembangkan dari hasil adaptasi Aziz (2015) sebelumnya yang berjumlah 24 item terhadap The Mental Health Inventory (MHI-38) yang dibuat oleh Veit \& Ware (1983) ini sejalan dengan temuan Aziz yang menunjukkan reliabilitas $=.888$ dan temuan Veit \& Ware yang menunjukkan reliabilitas $=.96$. Instrumen versi pendek (12 item) ini 
menunjukkan konsistensi yang baik dalam mengukur kesehatan mental mahasiswa, serta mampu membedakan mahasiswa dengan kesehatan mental tinggi dan rendah sebagaimana ditunjukkan pada nilai korelasi item total Psychological Well-being yang terentang dari .667-.757 dengan reliabilitas $=.885$ dan Psychological Distress yang terentang dari .486-.603 dengan reliabilitas $=.785$.

Hasil ini juga menunjukkan bahwa untuk memahami kesehatan mental maka tidak cukup dengan pemahaman terhindarnya dari tekanan psikologis atau tingginya tingkat kesejahteraan tapi harus melibatkan kedua aspek tersebut. Hal ini sejalan dengan pendapat yang dikatakan oleh Greenspoon \& Saklofske (2001) yang menyatakan bahwa meskipun kesejahteraan dan tekanan psikologis sering dikonseptualisasikan sebagai ujung yang berlawanan dari satu kesatuan, namun model alternatif mengusulkan bahwa kesejahteraan positif dan tekanan psikologis adalah dua konstruksi yang terkait tetapi unik yang berkontribusi terhadap kesehatan mental secara keseluruhan.

Lebih jauh lagi, Keyes (2013) melalui hasil penelitiannya menunjukkan secara signifikan bahwa model dua faktor sangat cocok untuk mendukung kesejahteraan psikologis (psychological wellbeing) dan tekanan psikologis (psikological distress) sebagai karakteristik yang dapat dikonseptualisasikan sebagai dua konstruksi terpisah, daripada kutub yang berlawanan pada satu dimensi. Hal ini dapat dibuktikan dari adanya berbagai profil kesehatan mental. Pendapat yang sama dikemukakan oleh Veit \& Ware (1983) kesehatan mental dapat mencakup aspek positif dan negatif. Aspek positif dalam kesehatan mental diartikan dengan psychological well-being serta kepuasan hidup, sedangkan aspek negatif diartikan sebagai terbebasnya individu dari psychological distress seperti stres, kecemasan, dan kehilangan kontrol.

Beberapa uraian di atas menunjukkan bahwa alat ukur kesehatan mental versi pendek (12 item) selanjutnya disebut sebagai alat ukur Brief Mental Health Inventory (BMHI-12) telah memenuhi persyaratan psikometris untuk digunakan dalam pengukuran kesehatan mental. Namun demikian, ada beberapa keterbatasan yang mungkin dapat dipertimbangkan dalam upaya perbaikan ke depan. Diantara hal penting yang harus dipertimbangkan untuk pengembangan alat ukur ini adalah adanya dua indikator pada aspek tekanan psikologis (depresi dan kehilangan kontrol) yang masih memiliki tingkat reliabilitas cukup sehingga perlu ditingkatkan. Selain itu, indikator pada tiap aspek kesehatan mental sangat mungkin berkembang seiring dengan perkembangan teori sehingga akan berdampak pada perlunya penambahan item pada alat ukurnya.

\section{REFERENSI}

Aziz, R. (2015). Aplikasi Model Rasch dalam Pengujian Alat Ukur Kesehatan Mental di Tempat Kerja. Psikoislamika, 12(1), 1-11. https://doi.org/10.18860/psi.v12i2.64 02

Bartels, M. (2015). Genetics of Wellbeing and Its Components Satisfaction with Life, Happiness, and Quality of Life: A Review and Meta-analysis of Heritability Studies. Behavior Genetics, 45(2), 137-156. https://doi.org/10.1007/s10519-0159713-y

Greenspoon, P. J., \& Saklofske, D. H. (2001). Toward an Integration of Subjective Well-Being and Psychopathology. 28.

Heinen, I., Bullinger, M., \& Kocalevent, R.D. (2017). Perceived stress in first 
year medical students-Associations with personal resources and emotional distress. BMC Medical Education, $\quad$ 17(1), 4. https://doi.org/10.1186/s12909-0160841-8

Keyes, C. L. (2002). The mental health continuum: From languishing to flourishing in life. Journal of Health and Social Behavior, 207-222.

Keyes, C. L. M. (Ed.). (2013). Mental WellBeing. Retrieved from http://link.springer.com/10.1007/978 -94-007-5195-8

Kirkcaldy, B. (Ed.). (2015). Promoting Psychological Wellbeing in Children and Families. https://doi.org/10.1057/97811374799 69

Meixner, T., Irwin, A., Wolfe Miscio, M., Cox, M., Woon, S., McKeough, T., \& Milligan, K. (2019). Delivery of Integra Mindfulness Martial Arts in the Secondary School Setting: Factors that Support Successful Implementation and Strategies for Navigating Implementation Challenges. School Mental Health, 11(3), 549-561. https://doi.org/10.1007/s12310-0189301-4

Nugraha, A. P., Ernawati, D. S., Harijanti, K., \& Parmadiati, A. E. (2018). Psychological Stress Induced Xerostomia and Hyposalivation: The Case Study in Indonesian Female Patient. Journal of International Dental and Medical Research, 12(1), 216-219.

Organization, W. H., \& others. (2004). Promoting mental health: Concepts, emerging evidence, practice: Summary report. Retrieved from http://apps.who.int/iris/handle/10665 142940
Steptoe, A., O'Donnell, K., Marmot, M., \& Wardle, J. (2008). Positive affect and psychosocial processes related to health. British Journal of Psychology, 99(2), 211-227. https://doi.org/10.1111/j.20448295.2008.tb00474.x

Tavolacci, M. P., Ladner, J., Grigioni, S., Richard, L., Villet, H., \& Dechelotte, P. (2013). Prevalence and association of perceived stress, substance use and behavioral addictions: A crosssectional study among university students in France, 2009-2011. BMC Public Health, 13(1), 724. https://doi.org/10.1186/1471-245813-724

Taylor, S. E., \& Brown, J. D. (1988). Illusion and well-being: A social psychological perspective on mental health. Psychological Bulletin, 103(2), 193.

Veit, C. T., \& Ware, J. E. (1983). The Structure of Psychological Distress and Well-Being in General Populations. Journal of Consulting and Clinical Psychology, 51(5), 730742.

Wahyuni, S., Anies, Soejoenoes, A., \& Putra, S. T. (2019). Psychoeducation Dzikr reduces perceived stress and postpartum depression syndromes on primiparous women. Indian Journal of Public Health Research and Development, 10(3), 946-951. https://doi.org/10.5958/09765506.2019 .00624 .7

Zamroni, Z. (2015). Prevalensi Stres Akademik Mahasiswa. Psikoislamika: Jurnal Psikologi dan Psikologi Islam, 12(2), 51. https://doi.org/10.18860/psi.v12i2.64 04 